\title{
THE CHALLENGES OF THE 21st CENTURY OF PPKN TEACHERS IN REDUCING STUDENTS OF GENERATION Z
}

\author{
Imelda Putri Parama Iswari ${ }^{1}$, Moses Glorino Rumambo Pandin ${ }^{2}$ \\ ${ }^{1}$ Indonesia Language and Literature Study Program, Faculty of Humanities, Airlangga University \\ ${ }^{2}$ Departement of English Language and Literature, Faculty of Humanities, Airlangga University
}

\begin{abstract}
In the 21 st century, many changes occur in life. The most prominent are technology-based and digital activities. Students born after 1995 are called Generation Z who play a role in creating and using various digital technologies. Generation $\mathrm{Z}$ in the 21 st century is a digital generation that continues to advance and create new things in the fields of technology, communication, and digital. To compensate for the changes that occur in the character of generation $\mathrm{Z}$ students and also the faster technological developments, the creativity of teachers is needed in making a learning innovation. Innovation is carried out so that the learning process does not lag behind the times when technology changes rapidly.
\end{abstract}

Keywords: Teachers, 21st Century, Generation Z, Globalization, Student Competence

\section{INTRODUCTION}

\section{Background}

Being a teacher is not an easy job. An educator is required to have a personality that has an extraordinary impact. Educators who are not sensitive to their surroundings can affect the psychology of their students. This is very dangerous because accepting the condition of students without an attitude of tolerance can worsen their psyche. Therefore, the teacher must understand as much as possible the condition of his students. As a figure that will be imitated by students, teachers should have a unique and directed personality.

Teachers take a huge responsibility to produce young people who can live their lives without crossing the limits of fairness and also instill good character or personality in facing the world with all the sophistication that exists. In addition, teachers as educators must also be able to control themselves during direct interaction with students because it will affect the mentality of their students.

Civic education is a subject related to the development of citizens. In preparing generation $\mathrm{Z}$ students who are critical, creative, innovative, and intelligent, of course, a qualified Civics teacher is needed. To prepare our children for this new world, we need to change the way we educate them. In the 21 st century, educators must create curricula that will help students connect with the world and understand the problems facing our world. There are children in today's era who have never been taught with technology but they can learn independently about any topic they are interested in without any tutorials from others (training student activity).

The classroom curriculum is designed to incorporate multiple skills and levels of intelligence utilizing technology and multimedia. Lessons are not based on textbooks, but rather project-based lessons. Skills are learned through their research and projects. In addition to a modern curriculum, teachers also need to cultivate and maintain the learning goals that students will face in the real world and must also try to increase the curiosity of their students, which will help them become lifelong learning students. 


\section{METHOD}

The method used in this study uses a library research method or approach, library research or literature can be interpreted as a series of activities related to the method of collecting library data, reading and taking notes, and processing research materials (Zed, 2003: 3). In literature research, there are at least four main characteristics that the author needs to pay attention to, including First, that the author or researcher deals directly with text (nash) or numerical data, not with direct knowledge from the field. Second, library data is "ready to use" which means that the researcher does not go directly to the field because the researcher is dealing directly with the data sources in the library. Third, that library data are generally secondary sources, in the sense that researchers obtain materials or data from second-hand sources and not original data from first-hand data in the field. Fourth, that the condition of the library data is not limited by space and time (Zed, 2003:4-5). Based on the foregoing, the data collection in research is carried out by reviewing and exploring several journals, books, and documents (both printed and electronic) as well as other sources of data or information deemed relevant to the research or study.

\section{RESULT}

\section{Generation}

A generation is a group of people who have the same year of birth, age, location, and also historical experiences or events within the same individual that have a significant influence on their growth phase. So, it can also be said that a generation is a group of individuals who experience the same events in the same period.

The challenges of teachers in the era of Generation $\mathrm{Z}$ are becoming increasingly difficult. Especially if the teacher was born in the era of generation $X$. He is required to keep pace with and catch up with the fast-changing lifestyles and abilities of generation $\mathrm{Z}$ children who are raised with digital technology. The challenges of teachers in the millennial and generation $\mathrm{Z}$ era are becoming increasingly complex because everything changes so quickly without being able to be filtered by teachers in schools. Teachers born from Generation $\mathrm{X}$ are very important to know the behavior of Generation $\mathrm{Z}$ if they want to be successful in teaching and educating this generation. As a generation born and raised in the digital era, children as students will be very close to social media. So far, Generation $\mathrm{Z}$ is known to be a less focused character than millennials, but more versatile; more individual, more global, more openminded, quicker to enter the workforce, more entrepreneurial, and of course more technology-friendly. 21 st-century learning is simply defined as learning that provides 21 st-century skills to students, namely the 4Cs which include: (1) Communication (2) Collaboration, (3) Critical Thinking and problem solving, and (4) Creative and Innovative.

However, apart from learning about the skills that students need to develop to be successful in the 21st century, namely what learning concepts are appropriate for teachers to retain or discard. One of the teacher's roles is to prepare students for the specific tasks they must complete. We don't live in the same world right now. Society is a mixture of many different beliefs and cultures. Globalization has opened up the world and allowed people to connect in new and exciting ways. We blend traditions and create unique belief systems that are not taught in any classroom but are developed through our experiences and passions. We transmit our values and culture without expecting them to be adopted by our audience. As usual, at its core, the role of education is to prepare students to become active, successful, and contributing members of society. The essence of the role of education has not changed. However, there are important changes to note. Society has changed, we cannot adequately prepare students for the society that exists today or that will exist tomorrow if we continue to prepare them for the society that existed yesterday. To prepare students to play their part in 21st-century society, there are several things 
to consider when deciding how education will look in our schools and classrooms. Some things teachers should do such as:

1. Instruction must be student-centered

Student-centered learning is highly encouraged in the 21 st century. This does not mean that teachers can never give lectures again. On the other hand, it means that the main source of knowledge in the classroom should not be the teacher alone. Education is no longer about listening to the teacher speaks and absorbing information. To contribute to society, students must be able to acquire new information when problems arise. Then they need to relate the new information to the knowledge they already have and apply it to solve existing problems. They won't be able to call on the teacher for answers, so need to "learn how to learn" on their own. In this classroom model, the teacher will act as a facilitator for students. Instead of passively receiving information, students will gather information on their own under the guidance of their teacher. Different learning styles are encouraged, and students have an enhanced sense of motivation and responsibility. They engage in a variety of hands-on activities and demonstrate learning in a variety of ways. Learning is about discovery, not memorizing facts.

2. Education must be collaborative

Students must learn how to collaborate with others. Today's society has people collaborating all over the world. How can students be expected to work with people from other cultures with values different from their own, if they cannot work with the people they see every day in their classrooms? Students should be encouraged to work together to find information, collect it, and construct meaning. Collaboration must also be dynamic. Students must learn how to recognize the different strengths and talents that each person can bring to a project, and change roles depending on those attributes. Schools should also collaborate with other educational institutions around the world to share information and learn about various practices or methods that have been developed. They must be willing to change their teaching methods in light of new advances.

3. Learning must have context

Student-centered does not mean that teachers give up all control over the class. While students are encouraged to learn in different ways, teachers still guide the skills that need to be acquired. Thus, students will be much more motivated to learn something they can see value for.

4. Schools must be integrated with the community

To prepare students to be responsible citizens, we need to model what a responsible citizen is. Schools will often work to achieve this by creating events for the school community, by encouraging students to join committees or take part in school projects, and by occasionally helping the community around them with activities such as food drives or neighborhood clean-ups. With the power of technology and the internet, today's students can do it more easily. Our community is no longer just an area of space located around the school, but reaches out and envelops the world. Education needs to help students take part in this global community and find ways to impact more than just their environment. Every learning that the Civics Teacher does in the classroom must meet the 4 abilities of students are Critical Thinking, Creativity, Collaboration, and Communication. The objectives for implementing these 4 competencies for Generation $\mathrm{Z}$ are as follows:

1. Critical Thinking

Students need the ability to think analytically, which includes proficiency with comparing, contrasting, evaluating, synthesizing, and applying without instruction or 
supervision. Why is this important? Analytical thinking means being able to use the higher end of Bloom's digital taxonomy or higher-order thinking skills (HOTS). Students need the ability to solve complex problems in real-time. Why is this important? In the future, complicated problems that we can't even imagine now will be everywhere. As society progresses, the complexity of manageable conflicts will also increase. The more we focus on students' abilities to find effective solutions to realworld problems, the more successful those students will be. Students are complex, energetic, and tech-savvy individuals. These are the kinds of people who would be successful in a global marketplace like ours. Such individuals are assets to any workforce. It is worth mentioning that in the future we are talking about, workers who are not able to think proactively to solve problems will have a hard time finding work.

\section{Creativity}

Students must be able to think and work creatively in both digital and non-digital environments to develop unique and useful solutions. Creativity is a vital channel that inspires students to see who they are and what they can do, and to realize what they can achieve. Any side of the student must be allowed to shine in their learning. Tasks that require linear thinking and routine cognitive work are increasingly being outsourced. So it is very important to guide students to be able to do analytical thinking. It is critical to their ability to succeed in life after class. Analytical thinking is an important part of what makes up Information Fluency. Analytical thinkers look at data and information in multiple dimensions, and from multiple angles. They are proficient in conceptualization, organization and classification, and synthesis of knowledge. These types of skills are invaluable because they enable students to practically deal with problems of a social, mathematical, and scientific nature. It empowers them to make effective and level-headed decisions in their lives and relationships. It's easy to see why critical thinking and analytical skills are important for success outside of school.

\section{Collaboration}

Students must have the ability to collaborate seamlessly in physical and virtual spaces, with real and virtual partners globally. Students in the digital age are social. The text, post, update, share, chat, and are constantly together in a technological environment with each other. When they are unable to do this in school, they become detached and detached from their learning. Connection and collaboration with others are essential not only to their learning but also to their mental and emotional health. This is a skill that educators should practice regularly, and understanding Collaboration Fluency will help in this regard.

\section{Communication}

Communication is an activity of transferring information both orally and in writing. However, not everyone can communicate well. Sometimes some people can convey all the information orally but not in writing or vice versa. Humans are social creatures who always interact with each other. Therefore, communication is one of the most important things in human civilization. The main purpose of communication is to send a message through the selected media so that it can be understood by the recipient of the message. Effective communication occurs when something (message) that is notified by the communicator can be received well or equally by the communicant so that there is no misperception. For communication between humans to be effective, proper communication techniques are needed. Communication technique is a method used in conveying information from communicator to communicant with certain media. With this technique, it is hoped that everyone can effectively communicate with each other and use it appropriately. 


\section{DISCUSSION}

A. Generation Z

According to Kupperschmidt (2000) (in Putra, 2016) Generation is a group of people who have the same year of birth, age, location as well as historical experiences or events within the same individual that have a significant influence on their growth phase. So, it can also be said that a generation is a group of individuals who experience the same events in the same period. In the generation theory (Generation Theory) proposed by Graeme Codrington \& Sue Grant-Marshall, Penguin, (2004) differentiated 5 human generations based on year of birth, namely:

1. Baby Boomer (born 1946 - 1964)

The generation born after World War II has many siblings, as a result of the many couples who dared to have many children. Adaptive generation, easy to accept and adapt. Regarded as old people who have life experience.

2. Generation X (born 1965-1980)

The years when this generation was born were the beginning of the use of PCs (personal computers), video games, cable tv, and the internet. Data storage also uses a floppy disk or floppy disk. MTV and video games are very popular these days. Some of this generation has negative behaviors such as disrespecting parents, getting to know punk music and trying to use marijuana.

3. Generation Y (born 1981-1994)

Known as the millennial generation or millennials. The phrase Generation Y began to be used in editorials of major United States newspapers in August 1993. This generation uses a lot of instant communication technologies such as email, SMS, instant messaging, and social media such as Facebook and Twitter. They also like to play online games.

4. Generation Z (born 1995-2010)

Also called generation, net generation, or internet generation. They have similarities with Generation Y, but they can apply all activities at one time such as tweeting using a cellphone, browsing on a PC, and listening to music using a headset. Whatever is done mostly related to the virtual world. Since childhood, they are familiar with technology and are familiar with sophisticated gadgets that indirectly affect their personality. 5. Generation Alpha (born 2011-2025)

Generations born after generation $\mathrm{Z}$, born from the late $\mathrm{X}$ and $\mathrm{Y}$ generations are the most educated generation because they go to school early and learn a lot, on average they have rich parents. This paper focuses on discussing the generation born from 1995 to 2010 or known as Generation Z. Generation Z has different characteristics from previous generations, the following are the characteristics of Generation Z:

1. Tech-savvy, tech-savvy, web-savvy, app-friendly generation.

They are the "digital generation" who are proficient and passionate about information technology and various computer applications. They can access the various information they need easily and quickly, both for the sake of education and the interests of their daily life.

2. Social.

They are very intense in interacting through social media with all walks of life. They are very intense in communicating and interacting with all walks of life, especially with their peers through various networking sites, such as FaceBook, Twitter, or via SMS. Through this medium, they can express what they feel and think spontaneously. 


\section{Expressive.}

They tend to be tolerant of cultural differences and care about the environment.

\section{Multitasking.}

They are used to various activities at the same time. They can read, talk, watch, or listen to music at the same time. They want things to be done and run fast. They do not want things that are long-winded and convoluted.

5. Quickly switch from one thought/job to another (fast switcher).

6. Happy to share.

The demands of the international community for the duties of Civics teachers entering the 21st century are not light. Teachers are expected to be able and able to organize a learning process that relies on upon and implements the four pillars of learning recommended by the UNESCO International Commission for education. communication designed to bring about Learning). UNESCO recommends four pillars in the field of education, namely:

1. Learning to know

Learning to know, namely the learning process to know, understand, and appreciate the ways of acquiring knowledge and education that provide students with the provision of knowledge.

2. Learning to do Learning to do, namely the process of learning to do or do something.

3. Learning to live together Learning to live together, namely, education should provide the ability to live together in a pluralistic society to create a peaceful life and an attitude of tolerance among fellow human beings.

4. Learning to be

Learning to be, education should provide the ability to develop oneself.

The 21st-century teacher has a vision for the future. They are aware of the ever-changing trends in technology and are in tune with what the future holds in education. A good 21st-century teacher is aware of the career opportunities that are coming in the years ahead for their students, and always advocates forethought and planning to ensure all students will not be left behind. Finally, 21st-century educators must use teaching strategies to ensure that the focus in education is on preparing today's children for the future where they will live and where they will work, not for our world today.

\section{CONCLUSION}

A teacher cannot stop technology for generation $\mathrm{Z}$ children. A teacher must be able to change the way of teaching and find the latest concepts so that students can also understand and prepare for the future well. In this era of the 21 st century, critical thinking, creativity, collaboration, and communication skills are very important for every student to master. This ability will provide provisions for students to develop themselves in the future. The conclusion from the explanation above is that in the 21st century, of course, many challenges will be faced by the people or citizens of Indonesia. Various advances in technology and information require humans to be able to contribute to it and blend in with the advances that have been presented in this 21st century. All forms of progress that have been there will certainly have a positive and negative impact on its citizens. Therefore it is necessary to have the knowledge and a strong identity so as not to get lost.Semuanya dapat ditindak lanjuti oleh warga 
negara dengan benar if it has a good or positive character. By having a character in themselves, citizens in the 21 st century will be able to respond to all forms of progress in a relaxed manner because they will not be surprised by the changes that occur. Citizens in the 21 st century are required to have characters that they can use as guidelines in interacting with other humans. and also as mental reinforcement in the face of various forms of changes that exist in the present century. To be able to become a citizen of the 21 st century, the thing that needs to be known is the importance of growing character values.

\section{REFERENCE}

1. Riskha Nur Fitriyah. TEACHER COMPETENCE DEVELOPMENT IN THE ERA OF THE INDUSTRIAL REVOLUTION 4.0 THROUGH EDUCATION AND TRAINING. 2019; (1): 359-364.

2. Susilo Setyo Utomo. TEACHERS IN THE ERA OF THE INDUSTRIAL REVOLUTION 4.0. 2019; (1): 70-83.

3. Duwi Retnaningsih. TEACHER CHALLENGES AND STRATEGIES IN THE ERA OF THE INDUSTRIAL REVOLUTION 4.0 IN IMPROVING THE QUALITY OF EDUCATION. 2019; (1): 23-30.

4. Akhmad Nur Fauzan. PPKN TEACHER'S STRATEGY IN DEVELOPING HIGHERORDER THINKING SKILLS-ORIENTED KNOWLEDGE ASSESSMENT INSTRUMENTS (STUDY AT SMA NEGERI 1 SURAKARTA).2019. (1): 1-10.

5. Tiarmayanti Novita Sonia. BECOME A TEACHER OF THE 21st CENTURY: ANSWERS TO THE CHALLENGE INDUSTRIAL REVOLUTION LEARNING 4.0. 2019; (1): 191-199.

6. Hermi Yanzi, Nafilah, Susana, Siti Patmawati. THE URGENCY OF TEACHERS IN THE 21st CENTURY ERA IN RESPONDING TO THE INDUSTRIAL REVOLUTION 4.0. 2019; (1): 324-334.

7. Rohmat Sulistya. HEUTAGOGY AS A TRAINING APPROACH FOR TEACHERS IN THE ERA OF THE INDUSTRIAL REVOLUTION 4.0. 2019; (1): 127-138.

8. Agus Supandi, Sara Sahrazad, Arief Nugroho Wibowo, Sigit Widiyarto. COMPETENCE ANALYSIS: LEARNING OF THE INDUSTRIAL REVOLUTION 4.0. 2020; (1): 1-6.

9. Syamsul Kurniawan. 21st CENTURY CHALLENGES FOR MADRASAH IN INDONESIA.2019; (1): 55-65.

10. Fanny Rahmatina Rahim, Dea Stevani Suherman, Murtiani Murtiani. ANALYSIS OF TEACHERS' COMPETENCE IN PREPARING LEARNING MEDIA BASED ON INFORMATION TECHNOLOGY IN THE INDUSTRIAL REVOLUTION-ERA 4.0. 2019; (1): 91-208. 